\title{
Improving the information resource management strategy in the process of modernizing an industrial enterprise
}

\author{
Aleksandr Borovkov ${ }^{1}$, Svetlana Ovchinnikova ${ }^{2,}{ }^{*}$, Alla Lyamina $^{3}$, and Tatyana Zheludkova ${ }^{1}$ \\ ${ }^{1}$ Nevinnomyssk State University of Humanities and Technology, Nevinnomyssk, Russia \\ ${ }^{2}$ I.T. Trubilin Kuban State Agrarian University, Krasnodar, Russia \\ ${ }^{3}$ North-Caucasus Federal University, Stavropol, Russia
}

\begin{abstract}
For a more successful formation of industrial production systems, an effective system for managing intellectual capital, knowledge and information is needed. An indispensable condition for the development of modern industry is the creation and use of information and knowledge. Industrial modernization requires an organizational and economic mechanism for resource management. When solving the problems of improving and technological development of production systems of industrial enterprises or business groups, a method for selecting a strategy for managing corporate information resources was developed. It is based on the consequences of economic monitoring of the state of the production system, which provides for the primary processing and assessment of the reliability of the results, creation of alternative predictive scenarios for changes in the state of the external and internal environment of the production system, expression of strategic goals and objectives of modernization, development of target criteria for achieving the results of modernization, alternative competing strategies for information and knowledge management, checking competing strategies against the target criterion, choosing a strategy to be applied in the improvement process. The transition to promising paths is permissible only under the condition of intensive modernization of industrial enterprises, carried out on the basis of those technical and economic decisions that will lead to the development and use of the latest NBIC technologies.
\end{abstract}

\section{Introduction}

The enterprise needs to modernize production in order to expand production and raise the efficiency of activities [1-4]. Modernization of today's production can be carried out in two ways: extensive and intensive [5-6].

Among others, the following problems are inherent in modern Russian business groups and industrial enterprises, which are directly related to the management of information resources:

\footnotetext{
*Corresponding author: Svetlana.swetlana-ov@yandex.ru
} 
- lack of understanding of the essence and role of information, its features in the formation of diverse enterprises and business groups;

- lack of research on organizational culture as a factor of information support for the formation of an industrial enterprise;

- lack of effective tools in enterprises and business groups for valuation and value management of corporate information;

- weakness of the methodological apparatus for managing information resources at the intracorporate level [7-9];

- small development of tools for managing information resources of innovation active production systems and economic consolidation of enterprises - innovators.

These problems are becoming systemic issues in the formation of industry in the country.

Determination in the choice of an appropriate strategy for the modernization and development of production systems is necessary for the effective functioning of the information resource management system [10].

The aim of the study is to improve the methods of managing information resources of industrial enterprises and business groups that carry out modernization and take measures for the technological development of their production systems, taking into account the peculiarities of their activities and the development of methodological support by the management of planning and implementing development projects.

\section{Methods and materials}

Under the information resource management strategy, we assume a long-term, qualitatively defined area of the development of production systems in the field of creation and use of information, intellectual capital and knowledge, which leads the production system to its goals. Figure 1 shows an enterprise information resource management strategy, which (in our opinion) is more successfully illustrated by the diagram.

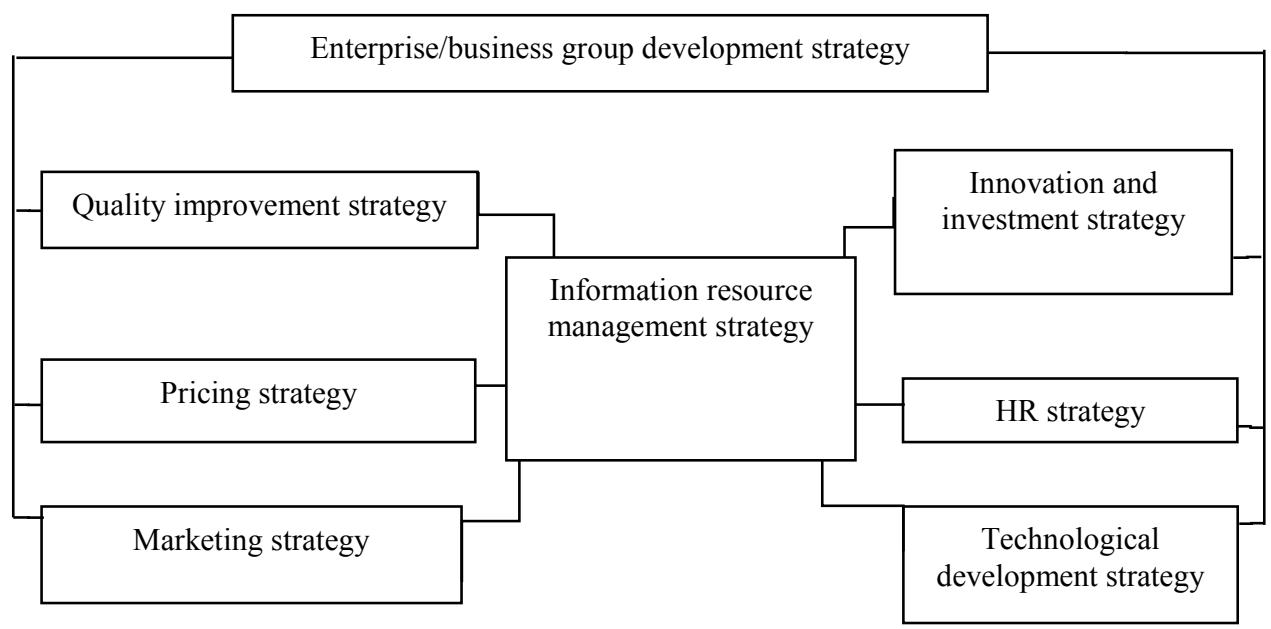

Fig. 1. Information resource management strategy in the overall development strategy of the enterprise.

In a knowledge economy and reindustrialization, enterprises that adhere to a knowledge leadership strategy can be competitive. When developing such a strategy, it is very important to establish strategic priorities in the management of information resources, among them it is important to highlight: values for the formation of intellectual assets; 
education and development of customer-oriented knowledge, protection of intellectual property (unique knowledge), IT systems and technologies for information resource management and knowledge transfer.

\section{Results}

A certain method has been developed for choosing the optimal strategy for managing information resources during the modernization and development of production systems in a particular enterprise (Fig. 2).

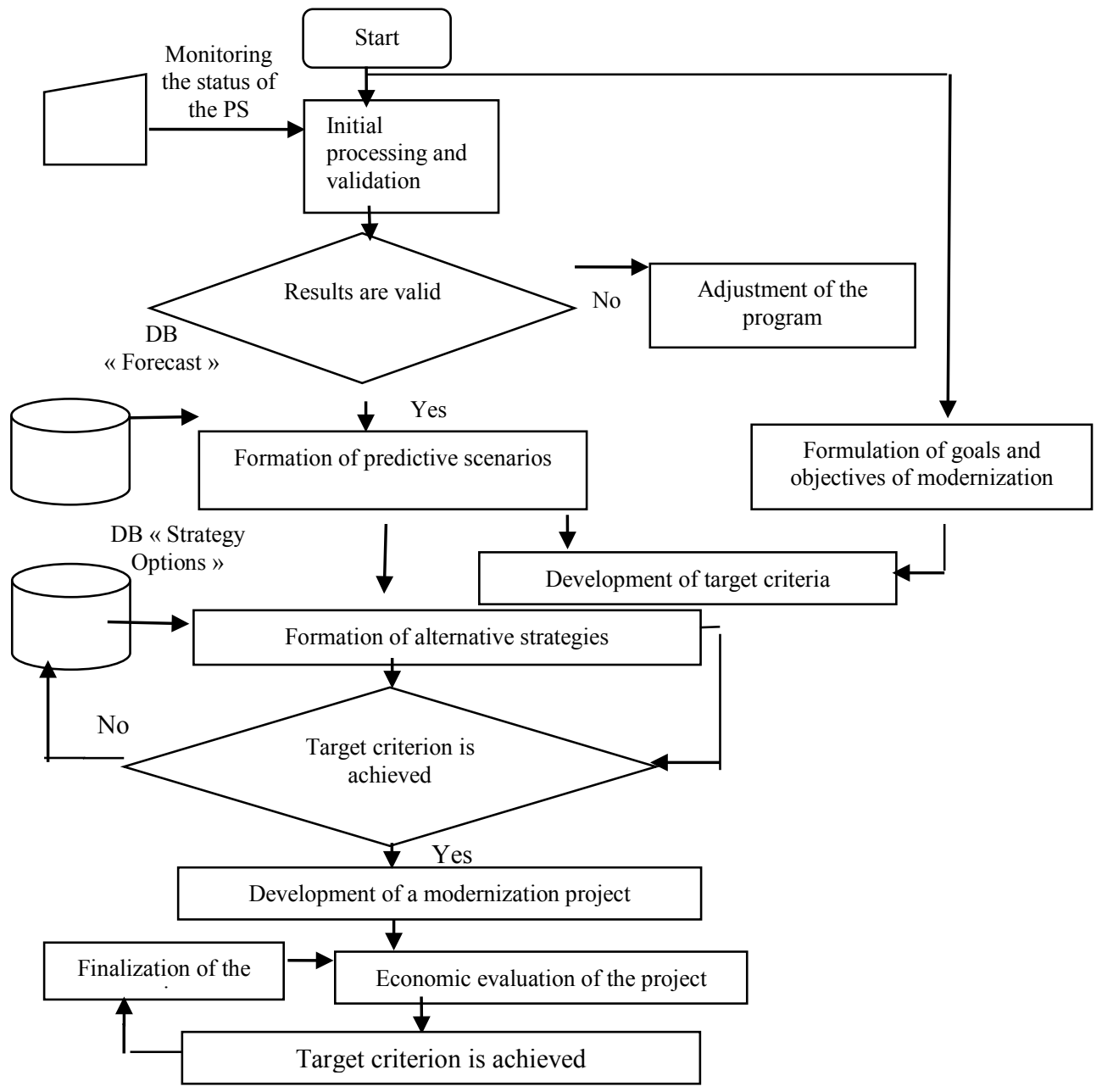

Fig. 2. Flowchart of choosing a strategy for managing information resources when modernizing a production system.

The developed methodology is based on the results of economic monitoring of the state of the production system, which predetermines the primary processing and assessment of the reliability of the monitoring results, development of alternative predictive scenarios for the transformation of the state of the external and internal environment, expression of strategic goals and objectives of modernization 
To preference rational priorities when developing a knowledge leadership strategy, it is necessary to understand the competitive position of an enterprise, which makes it possible to reasonably choose a strategy for managing information resources at industrial enterprises that modernize production systems and other actions for their technological formation.

When organizing leadership strategy modeling, three main indicators are recommended:

a) "industry leader" - an enterprise develops personal competitive advantages based on the creation of new knowledge on its own, which is further embodied in projects for the modernization of its production systems (including the production of new products);

b) "follower" - an enterprise that attracts professionals from outside and acquires knowledge from external resources. This strategy is short-lived. In this case, knowledge management is of a fickle nature, since the main goal of such a strategy is to avoid a significant lag behind the leader;

c) "outsider" - an enterprise does not carry out its own research and development, trying to save on the costs of information resources and their management, for the most part using "free" knowledge (table 1).

Table 1. Preference matrix when choosing strategies for managing information resources during modernization.

\begin{tabular}{|l|c|c|c|c|c|}
\hline \multirow{2}{*}{$\begin{array}{c}\text { Competitive } \\
\text { position }\end{array}$} & \multicolumn{4}{|c|}{ Knowledge management strategies for modernization } \\
\cline { 2 - 6 } & $\begin{array}{c}\text { Development } \\
\text { of intellectual } \\
\text { assets }\end{array}$ & $\begin{array}{c}\text { Development } \\
\text { of customer- } \\
\text { oriented } \\
\text { knowledge }\end{array}$ & $\begin{array}{c}\text { Generation } \\
\text { and } \\
\text { protection of } \\
\text { unique } \\
\text { buildings }\end{array}$ & $\begin{array}{c}\text { IT } \\
\text { systems } \\
\text { and } \\
\text { technolo } \\
\text { gies }\end{array}$ & $\begin{array}{c}\text { Knowle } \\
\text { dge } \\
\text { transfe } \\
\text { rengyyyyy}\end{array}$ \\
\hline "Industry leader" & 88 & 24 & 95 & 42 & 35 \\
\hline "Follower" & 31 & 36 & 42 & 56 & 73 \\
\hline "Outsider" & 41 & 85 & 33 & 25 & 74 \\
\hline
\end{tabular}

When developing a strategy for managing information resources in order to determine the correspondence of the competitive position of the enterprise and priorities, the calculation of data was implemented according to the algorithm presented in Fig. 2. Rational advantages are established for different competitive positions.

At the same time, the percentages of the considered situations were found for enterprises with different competitive positions.

The obtained results correspond to the logic of the choice of strategies. The "leader" enterprise is least of all interested in the transfer of knowledge (33\%).

During modernization, it focuses on the generation of new knowledge (95\%) and the management of intellectual assets accumulated in the previous stages (which allowed the enterprise to take the "leader" position).

On the other hand, the "outsider" enterprise, implementing improvement, is faced with the need to pay significant attention to the transfer of knowledge acquired by other business entities $(84 \%)$ and the personification of knowledge, assigning it to certain specialists involved in the development and implementation of improved projects.

\section{Discussion}

The proposed scheme of preference for the strategy of managing corporate information resources used in the modernization and development of production systems of an industrial enterprise or a business group includes economic monitoring of the state of the production system.

The proposed scheme provides for:

- initial processing and assessment of the accuracy of the monitoring results; 
- creation of alternative predictive scenarios for the modification of the external and internal environment of the production system;

- expression of strategic goals and objectives for improvement;

- development of targeted measures to achieve the consequences of modernization;

- development of many variable competing strategies for information and knowledge management;

- control of competing strategies according to the target criterion;

- selection of a strategy to be applied in the improvement process.

\section{Conclusions}

For effective activity, in management systems for the stable formation of production systems of enterprises and business groups, special subsystems for managing information, intellectual capital and knowledge are needed, which are a combination of interrelated and interdependent parts that synchronously act in the creation of knowledge, their accumulation and application in the implementation of organizational, technological and other changes in production systems.

\section{References}

1. S. Ovchinnikova, A. Borovkov, E. Schneider, A. Kalinichenk, E3S Web of Conferences 244, 01013 (2021) https://doi.org/10.1051/e3sconf/202124401013

2. S. Ovchinnikova, A. Borovkov, G. Kukinova, N. Markina, E3S Web of Conferences 244, 01007 (2021) https://doi.org/10.1051/e3sconf/202124401007

3. S. Ovchinnikova, M. Kalinichenko, N. Markina, E. Schneider, E3S W. of Conf. Energy $\begin{array}{lllll}\text { modernization of housing stock 157, } 06028 & \text { (2020) }\end{array}$ https://doi.org/10.1051/e3sconf/202015706028

4. B. Kozyrev, E. Tsoraeva, Al-Azawi Nagam, A. Chibirova, A. Kozyrev, E3S Web of Conferences 244, 03018 (2021) https://doi.org/10.1051/e3sconf/202124403018

5. E. Tsoraeva, A. Bekmurzov, S. Kozyrev, A. Khoziev, A. Kozyrev, E3S Web of Conferences 215, 02003 (2020) https://doi.org/10.1051/e3sconf/202021502003

6. E. Tsoraeva, S. Mezhyan, M. Kataeva, L. Hugaeva, T. Rogova, E3S Web of Conferences 224, 03001 (2020) https://doi.org/10.1051/e3sconf/202022403001

7. S.V. Ovchinnikova, A.Yu. Kalinichenko, A.A. Lyamina, E.M. Schneider, IOP Conf. Series: Materials Science and Engineering 1083, $012051 \quad$ (2021) https://doi.org/10.1088/1757-899X/1083/1/012051

8. V. Zhukov, E. Tsoraeva, A. Perov, IOP Conf. Series: Earth and Environmental Science 650, 012028 (2021) https://doi:10.1088/1755-1315/650/1/012028

9. E. Tsoraeva, R. Gadzhiev, S. Kuchiev, A. Pekh, S. Mezhyan, IOP Conf. Series: Materials Science and Engineering 1083, 012052 (2021) https://doi:10.1088/1757899X/1083/1/012052

10. S. Kovalevsky, N. Ravochkin and V. Shchennikov, E3S Web of Conferences 41, 04035 (2018) https://doi.org/10.1051/e3sconf/20184104035 